\title{
Morphometric Analysis of Skin in Different Body Regions of Young and Adult Red Sindhi Cattle Bos indicus
}

\author{
Imran Tarique $^{1 *}$, Muhammad Ghiasuddin Shah ${ }^{1}$, Illahi Bux Kalhoro ${ }^{1}$, \\ Zaheer Ahmed Nizamani ${ }^{2}$, Mansoor Tariq ${ }^{2}$, Jamil Ahmed Gandahi', \\ Saqib Ali Fazlani ${ }^{3}$ and Benazir Sahito ${ }^{3}$ \\ ${ }^{1}$ Department of Anatomy and Histology, Faculty of Animal Husbandry and Veterinary \\ Sciences, Sindh Agriculture University, Tandojam, Sindh 70060 \\ ${ }^{2}$ Department of Veterinary Pathology, Faculty of Animal Husbandry and Veterinary \\ Sciences, Sindh Agriculture University, Tandojam, Sindh 70060 \\ ${ }^{3}$ Department of Veterinary Pharmacology and Toxicology, Faculty of Animal Husbandry \\ and Veterinary Sciences, Sindh Agriculture University, Tandojam, Sindh 70060
}

\begin{abstract}
A B S T RAC T
The study is carried out on the histology and micrometrical analysis in skin of different body regions (dewlap, abdomen, scrotum / udder and thigh) of young and adult of either sex of red Sindhi cattle (Bos indicus). Skin of red Sindhi cattle showed epidermis thickness rang of 41.1-50.13 $\mu \mathrm{m}$ and dermis thickness rang of 443.97-597.05 $\mu \mathrm{m}$ in all body regions and significant $(P<0.05)$ in age and sex group. The epidermis possessed stratified squamous epithelium, and main cells was keratinocytes. The dermalepidermal junction was regular with an absence of dermal papillae and epidermal ridges. Dermis layer possess dens irregular connective tissue, which consist of elastic, collagen and reticular fibers. Superficial dermal papillary layer was located beneath the epidermis, whereas dermal reticular layer deeper above the hypodermis. The papillary and reticular dermis was well developed in adult male age group with abundant areolar and dense irregular connective tissue all skin regions. Skin appendages (sebaceous and sweat gland, and hair follicle) was well developed and distributed in papillary and reticular layer in adult age group, while in young age group mainly observed at papillary dermal layer of all body regions. Sweat gland was mainly baggy-tubular shaped based on L/D ratio 7.64 to 8.3 range in all body skin regions, contain higher volume $\left(3.2 \pm 0.1 \mu 3 \times 10^{-6}\right.$ and $\left.3.9 \pm 0.1 \mu 3 \times 10^{-6}\right)$ in dewlap and thigh body region of adult age group. Whereas numbers of sweat gland $/ \mathrm{cm}^{2}$ were observed more in abdomen body region of young than adult age groups and in thigh followed dewlap region of adult group than young age group.
\end{abstract}

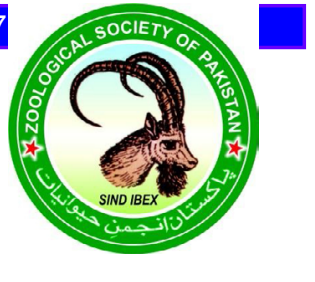

Article Information
Received 20 October 2019
Revised 02 January 2020
Accepted 14 January 2020
Available online 15 June 2021
Authors' Contribution
IT and MGS designed the study and
led the project. IT carried out the
experiments and wrote the article.
IT and MT revised the article and
analyzed the data. IBX, ZAN, SAF
and BS supervised and assisted in
study.
Key words
Red sindhi cattle, Skin,
Histomophology, Micrometry, Sweat
gland

\section{INTRODUCTION}

$B_{a}^{o s}$ os indicus, known as humped or indicus cattle, are a type of domestic cattle originating in South Asia. These cattle are characterized by a fatty hump on their shoulders, drooping ears, and a large dewlap (Khan et al., 2008), maintaining their body temperature by regulating the balance of heat gain and heat loss (Hahn, 1999). Though it has been shown that evaporative cooling by sweating is the most important mechanism for heat dissipation in an elevated temperature climate (Findly and Robertshaw, 1965; Kadzere et al., 2002), the skin microstructures play a vital role under harsh climatic condition as a temperature regulator, barrier, immune regulation etc.

Skin is the largest organ system of the body

\footnotetext{
Corresponding author: samoo imran88@hotmail.com 0030-9923/2021/0005-1609 \$ 9.00/0

Copyright 2021 Zoological Society of Pakistan
}

(Dalman, 1993), consisting of epidermis which is an avascular outer layer that performs its function as a barrier to protect from harmful substances and also prevent water and other essential substance from escaping the body (Vella, 1994). Dermis or the "true skin" is thick and lies immediately underneath of the epidermis (Ebling et al., 1992; Humbert, 2017). Skin appendages derived from interaction of epidermis and dermis are characterized as protrusions out of the body surface like hair, feather, scale, etc. and other invaginate to form sebaceous gland, sweat gland, etc. (Widelitz, 1997). Sweat gland in Bos indicus characterized as baggy-shape with higher density and volume, tend to be involved in higher sweating rate and closer to the skin surface (Allen, 1962; Dowling, 1955; Schleger and Turner, 1965; Pan, 1963; Nay and Hayman, 1956). Their duct open to the skin's surface via the hair follicle (Jenkinson and Nay, 1968; Beatty et al., 2006). Hair follicle's higher density provides higher protection against the radiant heat gain (McDowell, 1972; Turner and Schleger, 1960). 
The original home tract of red Sindhi breed is around Karachi, including hilly areas of Mahal Kohistan of Baluchistan. This breed has been imported by many countries (Wahid, 1975) not only because of more resistant ability under harsh climatic environments but also some tropical diseases as compared to crossbreeds due to distinctive feature of loose skin coat and thickness of skin (Sajid et al., 2007). The mechanisms that elaborate its enhanced tolerance are attributed to the futuristic heat dissipation ability through the skin surface, therefore skin and coat complications are a common source of concern in animal husbandry practice. Hence, current study was designed to investigate the skin micro-structures of red Sindhi cattle in different body regions to reveal their possible relationship with thermotolerance and to help understand the skin functions.

\section{MATERIALS AND METHODS}

\section{Animals}

All protocols were followed ethically and performed at the Key Laboratory of Anatomy and Histology Department, Faculty of Animal Husbandry and Veterinary Sciences, Sindh Agriculture University, Tandojam, Sindh, Pakistan. The experiment used 20 animals of red Sindhi cattle from a commercial herd located in city of Hyderabad premises, Sindh province, Pakistan. They were divided into four groups each of 5 animals namely 3-5 years old adult male (A.M), adult 3-5 years old female (A.F), young 6-18 months old male (Y.M) and young 6-18 months old female (Y.F).

\section{Sampling}

Skin biopsy for samples was performed in the summer, as per the technique described by Carter and Dowling and cited by Bianchini et al. (2006). Sampling was carried out by using skin puncher. Samples were collected from dewlap, abdomen, scrotum, udder and thigh body region, subsequently the skin samples were stripped of subcutaneous fat tissue using a scalpel. All skin samples were previously shaved and antiseptically performed with alcohol-iodoalcohol, and then local anesthesia was applied by infiltration.

\section{Histological preparations}

The samples were fixed in $10 \%$ neutral buffered formalin overnight immediately after collection, and then paraffin blocks were prepared. Sectioning was performed at $5 \mu \mathrm{m}$. The sections were stained with hematoxylin and eosin for light microscopic analysis using an Olympus microscope (BX53), camera (Olympus DP73, Japan) (Tarique et al., 2019).

\section{Micrometric analysis}

The detailed micrometric data of histo-structures, including thickness of epidermis, dermis and sweat gland were collected. For characterization of sweat gland, sweat gland shape (length and diameter ratio to determine saclike or tubular shape), sweat gland volume (formula= $\pi(1 / 2 \mathrm{D})^{2} \mathrm{~L}$; where $\mathrm{D}$ is diameter and $\mathrm{L}$ is length) and sweat glands per $\mathrm{cm}^{2}$ (number of glands per $\mathrm{mm}$ and value squared and multiplied by 100 ) were determinded (Jenkinson and Nay, 1968; Nay and Hayman, 1956; Udo, 1978; Nascimento et al., 2015).

All micrometrical collected data presented as mean \pm S.E.M, were measured by using the Image Pro v10 and analyzed statistically and presented by using Origin Pro 2018. Duncan's multiple range test was also used to detect significant differences $(\mathrm{P}<0.05)$.

\section{RESULTS}

The general histological skin structure in red sindhi cattle was similar to those reported in domestic mammals. It was found that skin of red sindhi cattle was composed of epidermis and dermis layer in all age groups of both sexes (Fig. 1).

\section{Skin histology of red Sindhi cattle}

Under the histological sections the skin of red sindhi cattle from young and adult male and female, the epidermis possessed stratified squamous epithelium, and main cells was keratinocytes, free of blood vessels consist of four layers arranged from outer to the inner as corneal layer, granulosum layer, spinosum layer and basal layer; this layer consisting of a row of columnar cells with elongated nuclear a dark color, while the spinosum layer consisting of several layers of polyhedral cell. The dermalepidermal junction was regular with an absence of dermal papillae and epidermal ridges (Fig. 1). The underlying dermis layer in all skin regions of red sindhi cattle were dens irregular connective tissue, which consist of elastic, collagen and reticular fibers. It was divided into two layers: superficial papillary layer is located beneath the epidermis and reticular layer, there is no clear line of demarcation, the reticular was much thicker than papillary layer. The papillary and reticular dermis was well developed in adult age groups with abundant areolar and dense irregular connective tissue in all skin regions (Fig. 1).

Furthermore, skin appendages (sebaceous gland, sweat gland and hair follicle) in adult age group was distributed papillary to reticular dermis in dewlap and abdomen, while in scrotum and thigh region mainly located in papillary dermis. However, in young age group, the skin appendages mostly lie in papillary dermis layer of all skin 
regions (Fig. 1). Sebaceous glands are located at the lower of hair follicles on both sides and drain their secretory port directly into the hair canal, whereas the sweat gland lies below sebaceous gland and directly open their duct into the skin or into the hair canal. Hair follicles are numerously present in the abdomen skin of adult age group and thigh skin region of young age group (Figs. 1 and 2).
Comparative micrometric analysis of thickness of skin layers Comparison of thickness of epidermis and dermis layers in different regions of skin in shown in Figures 3, 4 and Table I. The thickness of epidermis was higher in young than adult age groups of either sexes, while thickness of dermis was higher in adult age than young age group of either sexes. The highest epidermis thickness was observed in
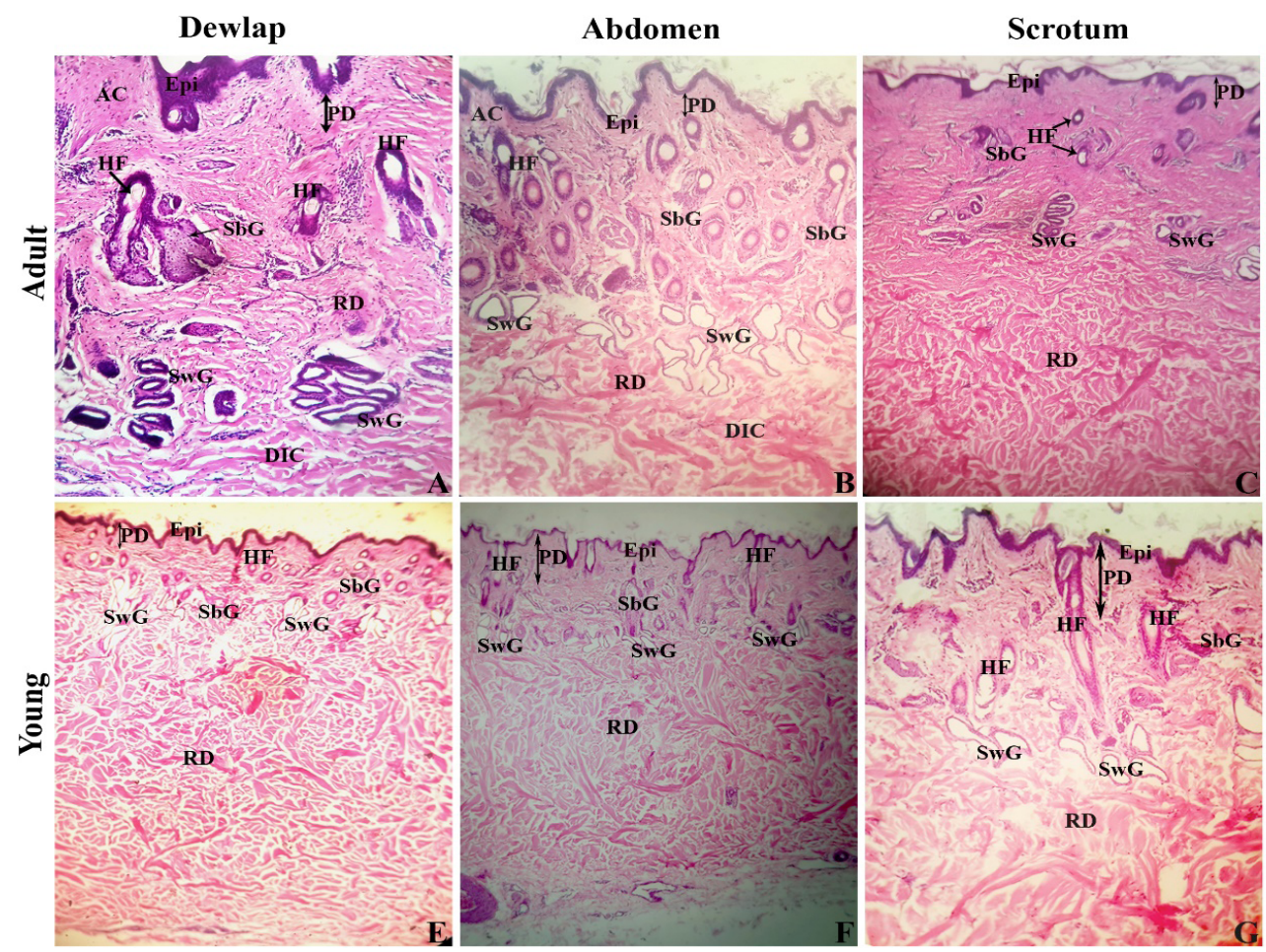

Thigh
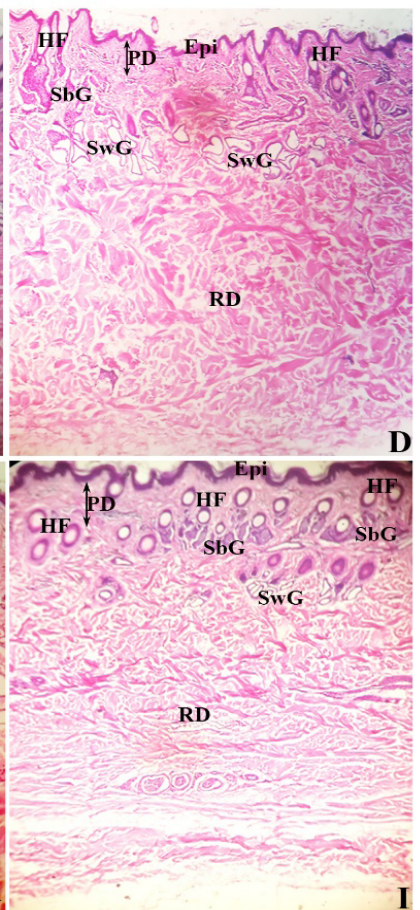

Fig. 1. Comparative histological structure of red Sindhi cattle. Epi, epidermis; AC, areolar connective tissue; PD, papillary dermis; RD, reticular dermis; HF, hair follicle; SbG, sebaceous gland; SwG, sweat gland; DIC, dense irregular connective tissue. Scale bar $=100 \mu \mathrm{m}(\mathrm{A}-\mathrm{I})$.

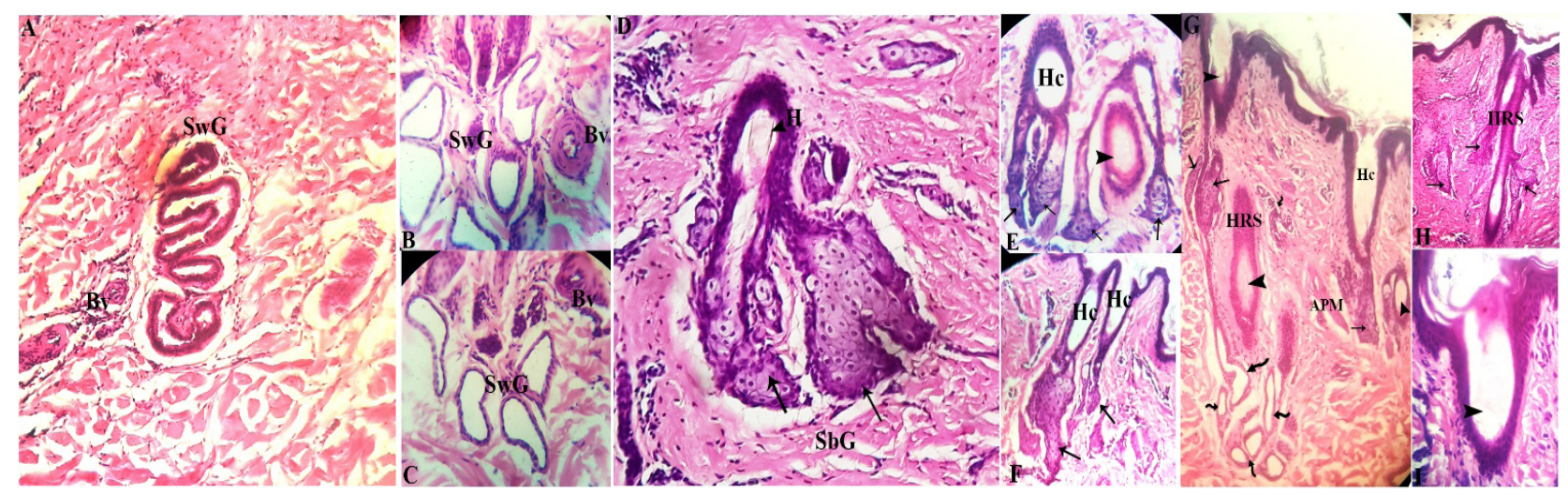

Fig. 2. Histological structure of skin appendages of red Sindhi cattle. SbG, sebaceous gland (arrow); SwG, sweat gland (curved arrow); HF, hair follicle (arrowhead); Hc, hair canal; HRS, hair root sheath; Bv, blood vessel. 
thigh regions of all age and sex groups (Fig. 3A). Moreover, result of total dermal skin thickness indicate no obvious variations in age and sex groups (Fig. 3B). Whereas layers of dermis show that papillary dermis thickness increases with age in both male and female groups. They varied in all body skin regions of all age groups of male and female. The reticular dermal ayer increases from young to adult age group in both sexes but is of consistent thickness in all body skin regions (Fig. 3C, D).
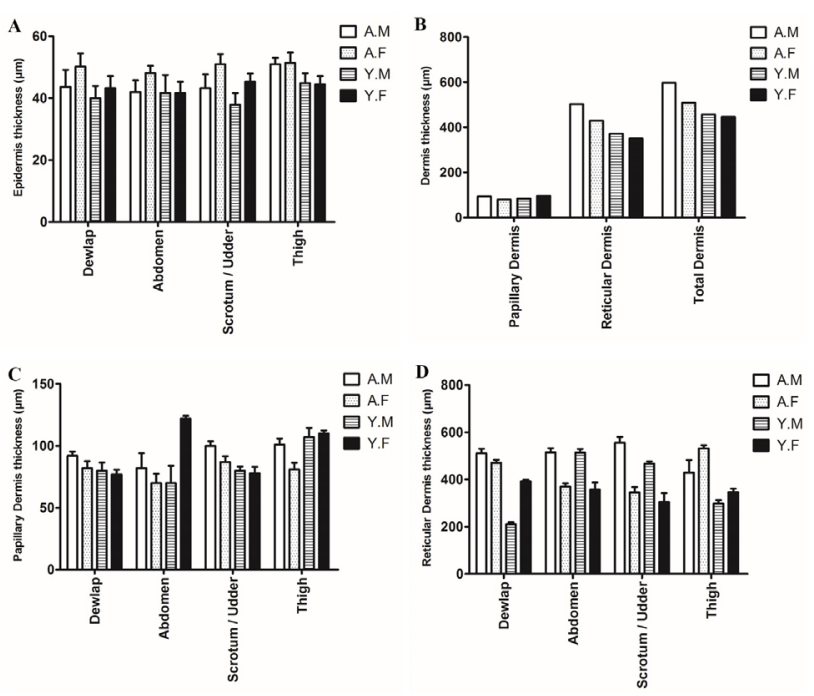

Fig. 3. Thickness $(\mu \mathrm{m})$ of skin layers in different regions of male (adult and young) and female (adult and young) red Sindhi cattle. Data presented as Mean \pm SEM. A.M, adult male; A.F, adult female; Y.M, young male; Y.F, young female.
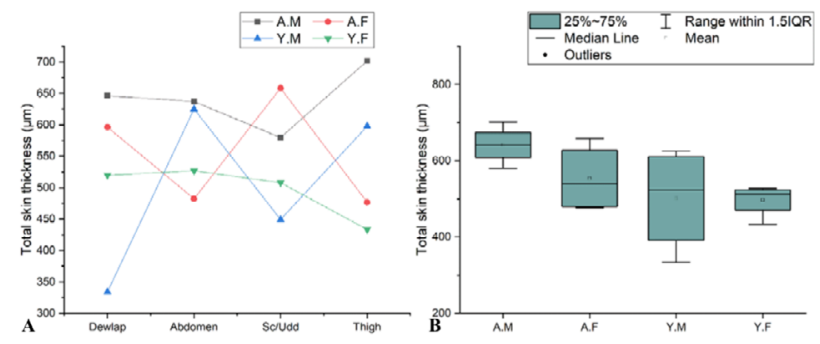

Fig. 4. Thickness $(\mu \mathrm{m})$ of Total skin layer of red Sindhi cattle. A, Comparative curve lines among adult and young genders from dewlap to thigh regions. B, Box plot showing the pattern of quantitative data of adult and young genders.

Total skin thickness in red sindhi cattle increases with age in dewlap, scrotum and udder skin region in male and female group. The total skin thickness is higher in dewlap, abdomen and thigh region in adult male, whereas variation exists in all regions of total skin of young males and females. The total skin thickness in scrotum of male and udder of female increases with age (Fig. 4A). Box plotting was analyzed to demonstrate the quantitative pattern of all age sex group (Fig. 4B).

\section{Micrometric analysis of sweat gland parameters}

Table II presents the sweat gland parameters in skin regions of red sindhi cattle. Sweat gland length, diameter, $\mathrm{L} / \mathrm{D}$ ratio, volume and numbers/ $\mathrm{cm}^{2}$ observed in both sexes of different age groups. The length and diameter of sweat gland showed significantly higher values in dewlap and thigh regions of adult male and female. The $\mathrm{L} / \mathrm{D}$ ratio

Table I. Thickness of skin layers in different regions of red Sindhi cattle. ANOVA interaction significantly shows $P$ value. Mean \pm SEM within a row with different superscript alphabet are significantly different $(\mathbf{P}<0.01)$.

\begin{tabular}{|c|c|c|c|c|c|c|}
\hline Skin regions & Adult male & Adult female & Young male & Young female & Range & P value \\
\hline \multicolumn{7}{|l|}{ Dermis } \\
\hline Dewlap & $603.2 \pm 0.8^{\mathrm{a}}$ & $552.8 \pm 1.7^{\mathrm{b}}$ & $290.7 \pm 0.9^{\mathrm{c}}$ & $468.7 \pm 1.6^{\mathrm{d}}$ & $290.7-603.2$ & $\mathrm{P}<0.05$ \\
\hline Abdomen & $596.2 \pm 1.1^{\mathrm{a}}$ & $440.2 \pm 1.5^{b}$ & $583.9 \pm 1.1^{\mathrm{ab}}$ & $468.7 \pm 1.4^{b}$ & $440.2-583.9$ & $\mathrm{P}<0.05$ \\
\hline Scrotum & $656.9 \pm 0.9^{\mathrm{a}}$ & & $547.3 \pm 1.3^{\mathrm{bc}}$ & & $547.3-656.9$ & $\mathrm{P}<0.05$ \\
\hline Udder & & $431.5 \pm 1.1^{\mathrm{ab}}$ & & $382.5 \pm 1.1^{\mathrm{c}}$ & $382.5-431.5$ & $\mathrm{P}<0.05$ \\
\hline Thigh & $531.9 \pm 1.4^{\mathrm{a}}$ & $612.5 \pm 1.1^{\mathrm{b}}$ & $405.5 \pm 0.7^{\mathrm{c}}$ & $456 \pm 1.6^{c}$ & $405.5-612.5$ & $\mathrm{P}<0.05$ \\
\hline Average & 597.05 & 509.25 & 456.85 & 443.97 & $443.97-597.05$ & \\
\hline \multicolumn{7}{|l|}{ Epidermis } \\
\hline Dewlap & $39.9 \pm 0.9^{a}$ & $43.3 \pm 1.0^{\mathrm{b}}$ & $43.7 \pm 0.7^{b}$ & $50.02 \pm 0.6^{\mathrm{b}}$ & $39.9-50.02$ & $\mathrm{P}<0.05$ \\
\hline Abdomen & $41.6 \pm 0.9^{\mathrm{a}}$ & $41.6 \pm 0.7^{b}$ & $42.1 \pm 0.9^{b}$ & $48.1 \pm 0.9^{b}$ & $41.6-48.1$ & $\mathrm{P}<0.05$ \\
\hline Scrotum & $37.9 \pm 1.1^{\mathrm{a}}$ & & $43.3 \pm 1.1^{\mathrm{b}}$ & & $37.9-43.3$ & $\mathrm{P}<0.05$ \\
\hline Udder & & $45.3 \pm 1.1^{\mathrm{b}}$ & & $51 \pm 1.0^{\mathrm{c}}$ & $45.3-51$ & $\mathrm{P}<0.05$ \\
\hline Thigh & $44.9 \pm 1.5^{\mathrm{a}}$ & $44.5 \pm 0.9^{\mathrm{a}}$ & $51 \pm 1.7^{b}$ & $51.4 \pm 1.1^{\mathrm{c}}$ & $44.5-51.4$ & $\mathrm{P}<0.05$ \\
\hline Average & 41.1 & 43.7 & 48.45 & 50.13 & $41.1-50.13$ & \\
\hline $\begin{array}{l}\text { Total skin thickness } \\
\text { (Epidermis + Dermis) }\end{array}$ & 639 & 552.95 & 505.3 & 494.1 & $494.1-639$ & \\
\hline
\end{tabular}


Table II. Sweat gland parameters in the skin layers of red Sindhi cattle. ANOVA interaction significantly shows $P$ value. Mean \pm SEM within a row with different lower-case alphabet are significantly different $(P<0.01)$.

\begin{tabular}{|c|c|c|c|c|c|}
\hline Skin regions & Adult male & Adult female & Young male & Young female & P value \\
\hline \multicolumn{6}{|l|}{ Length } \\
\hline Dewlap & $136.7 \pm 13 \mathrm{a}$ & $127.8 \pm 6.5 \mathrm{ab}$ & $90.44 \pm 7.2 \mathrm{bc}$ & $86.36 \pm 7.7 \mathrm{~d}$ & $\mathrm{P}<0.01$ \\
\hline Abdomen & $126.5 \pm 12.4 \mathrm{a}$ & $119.7 \pm 4.5 \mathrm{ab}$ & $82.28 \pm 4.5 \mathrm{~cd}$ & $81.6 \pm 6.5 \mathrm{~cd}$ & $\mathrm{P}<0.01$ \\
\hline $\mathrm{Sc} / \mathrm{Udd}$ & $114.9 \pm 14.1 \mathrm{a}$ & $110.2 \pm 5.1 \mathrm{~b}$ & $72.76 \pm 1.8 \mathrm{c}$ & $71.4 \pm 4.2 \mathrm{~d}$ & $\mathrm{P}<0.01$ \\
\hline Thigh & $146.9 \pm 7.2 \mathrm{a}$ & $140.1 \pm 8.8 \mathrm{ab}$ & $99.28 \pm 7.7 \mathrm{~cd}$ & $99.28 \pm 10.6 \mathrm{~cd}$ & $\mathrm{P}<0.01$ \\
\hline \multicolumn{6}{|l|}{ Diameter } \\
\hline Dewlap & $17.33 \pm 0.6 \mathrm{a}$ & $16.73 \pm 0.6 \mathrm{ab}$ & $11.53 \pm 0.5 \mathrm{~cd}$ & $10.53 \pm 0.5 \mathrm{~cd}$ & $\mathrm{P}<0.01$ \\
\hline Abdomen & $16.52 \pm 0.6 \mathrm{a}$ & $15.23 \pm 0.5 \mathrm{ab}$ & $10.27 \pm 0.5 \mathrm{~cd}$ & $10.1 \pm 0.5 \mathrm{~cd}$ & $\mathrm{P}<0.01$ \\
\hline Sc/Udd & $14.63 \pm 0.5 \mathrm{a}$ & $13.64 \pm 0.5 \mathrm{ab}$ & $9.4 \pm 0.6 \mathrm{~cd}$ & $9.27 \pm 0.5 \mathrm{~cd}$ & $\mathrm{P}<0.01$ \\
\hline Thigh & $18.48 \pm 0.6 \mathrm{a}$ & $17.35 \pm 0.5 \mathrm{ab}$ & $12.1 \pm 0.5 \mathrm{~cd}$ & $12.27 \pm 0.5 \mathrm{~cd}$ & $\mathrm{P}<0.01$ \\
\hline \multicolumn{6}{|l|}{ L/D } \\
\hline Dewlap & $8.1 \pm 0.05 \mathrm{a}$ & $7.6 \pm 0.05 b$ & $7.7 \pm 0.1 b c$ & $8.1 \pm 0.05 \mathrm{abd}$ & $\mathrm{P}<0.01$ \\
\hline Abdomen & $7.76 \pm 0.1 \mathrm{a}$ & $7.8 \pm 0.05 \mathrm{a}$ & $7.96 \pm 0.1 \mathrm{a}$ & $7.96 \pm 0.08 \mathrm{a}$ & $\mathrm{P}>0.01$ \\
\hline Scrotum/Udder & $7.87 \pm 0.1 \mathrm{a}$ & $8.03 \pm 0.1 \mathrm{a}$ & $7.64 \pm 0.1 \mathrm{a}$ & $7.83 \pm 0.1 \mathrm{a}$ & $\mathrm{P}>0.01$ \\
\hline Thigh & $8.3 \pm 0.1 \mathrm{a}$ & $8.2 \pm 0.1 \mathrm{a}$ & $8.1 \pm 0.05 \mathrm{a}$ & $8 \pm 0.02 \mathrm{a}$ & $\mathrm{P}>0.01$ \\
\hline \multicolumn{6}{|c|}{ Volume $(\mu 3 \times 10-6)$} \\
\hline Dewlap & $3.2 \pm 0.1 \mathrm{a}$ & $3 \pm 0.1 \mathrm{~b}$ & $0.8 \pm 0.03 c$ & $0.7 \pm 0.05 \mathrm{~d}$ & $\mathrm{P}<0.01$ \\
\hline Abdomen & $2.8 \pm 0.1 \mathrm{a}$ & $2.1 \pm 0.1 b$ & $0.7 \pm 0.05 \mathrm{c}$ & $0.7 \pm 0.05 \mathrm{~d}$ & $\mathrm{P}<0.01$ \\
\hline $\mathrm{Sc} / \mathrm{Udd}$ & $1.9 \pm 0.1 \mathrm{a}$ & $1.7 \pm 0.1 \mathrm{~b}$ & $0.6 \pm 0.05 \mathrm{~cd}$ & $0.4 \pm 0.08$ & $\mathrm{P}<0.01$ \\
\hline Thigh & $3.9 \pm 0.1 \mathrm{a}$ & $3.3 \pm 0.1 \mathrm{ab}$ & $1.1 \pm 0.05 \mathrm{~cd}$ & $1.1 \pm 0.05 \mathrm{~cd}$ & $\mathrm{P}<0.01$ \\
\hline \multicolumn{6}{|l|}{ Numbers / cm2 } \\
\hline Dewlap & 2265 & 2011 & 1285 & 1428 & \\
\hline Abdomen & 1277 & 1176 & 917.4 & 899.9 & \\
\hline Scrotum/Udder & 160.2 & 597.3 & 81.6 & 161.6 & \\
\hline Thigh & 377.1 & 343 & 177.4 & 174.5 & \\
\hline
\end{tabular}

showed no statistically difference in all age and sex groups. The volume of sweat gland on the other hand showed statistically significant increase in all age and sex groups. The higher values were observed in dewlap and thigh skin regions. However, the numbers of sweat gland/ $\mathrm{cm}^{2}$ increased in all skin regions of both sexes but were observed more in abdomen of young age and dewlap and thigh skin regions of adult age group of red Sindhi cattle.

\section{DISCUSSION}

The histological observation in present study showed that skin of red sindhi cattle consisted of epidermis and dermis. These histoarchitecture in different body skin regions were the same as described by others (Petrishchev and Lebengarts, 1993; Shalimov and Katsy, 1989; Yang et al., 2017).

The epidermis thickness in red sindhi cattle was significant in age and sex groups and ranged from 41.1$50.13 \mu \mathrm{m}$. Similarly, in cattle $(45.37 \mu \mathrm{m})$ (Hossain et al., 2016) and buffalo (50 $\mu \mathrm{m})($ Hafez et al., 1955) mean epidermal skin thickness was reported. In current study the thickest epidermis skin was noted in thigh region of all group, whereas thinnest in lower body skin regions. This variation of epidermal thickness has previously been reported in sheep and goat and suggested that epidermis thickness was highest in the skin on the back compared to lower skin regions in all age and sexes groups of both sexes (Mobini, 2012; Britt et al., 1985; Genkovski and Gerchev, 2007). Comparing sex group for epidermal thickness, female age group showed significant thickness than male age group. These results are contrary to those of native cattle of Bangladesh and in black goat (Sultan, 2012; Hossain et al., 2016). Humbert et al. (2017) reported $1 \mathrm{~mm}$ dermal skin thickness, whereas dermal papillary and reticular layers of Jersey cattle was suggested $1.22 \mathrm{~mm}$ and $4.01 \mathrm{~mm}$ respectively. In murrah and graded murrah buffalo highest thickness of papillary layer was $1.18 \mathrm{~mm}$ and $1.15 \mathrm{~mm}$, and that of reticular layer $4.91 \mathrm{~mm}$ and $3.74 \mathrm{~mm}$, respectively (Muralidharan and Ramesh, 2005). 
Dermal skin thickness of red sindhi cattle in present study ranged between 443.97-597.05 $\mu \mathrm{m}$ and both papillary and reticular dermal layer thickness increased with age in male and female group. Above reported studies of dermal and its layers thickness were found contrary to present study. However in Sindhi cattle papillary highest thickness was $0.62 \mathrm{~mm}$ and reticular lower thickness was 2.63mm (Muralidharan and Ramesh, 2005). These mean and ranging values were found partially similar to the current study results; difference in values could be due to the selection of body region and of different breed. The thickness of dermis and its layers was significant in all body regions and male group showed significant thickness compared with female age group, as reported in skin thickness analysis of cow and pig (Kobayashi et al., 1999) and in cattle (Hossain et al., 2016). Male showed significant total skin thickness comparing with female group of red sindhi cattle. It is suggested that male hormone, androgen is responsible for the collagen structure and regulation in the skin (Markova et al., 2004), which indicate significant difference in thickness of male and female.

Sweat gland is involved in cutaneous evaporative heat loss via their baggy shape and higher volume (Allen, 1962). The classification of sweat gland shape based on $\mathrm{L} / \mathrm{D}$ ratio was baggy shape $(<8)$ and tubular shape $(>8-12)$ (Jenkinson and Nay, 1973), thus in current study sweat gland showed 7.64 to 8.3 range of L/D ratio, and highest volume in dewlap and thigh skin region of all group. Suggesting that red Sindhi cattle possessed mainly baggy shaped sweat gland with higher volume depends upon the skin of body region. Different breeds showed bigger and varied sized of sweat gland due to great genetic mixture (Nay and Hayman, 1956; Pan, 1963), as previously reported in cattle of Asian and African breeds (8.59 and 8.36) (Jenkinson and Nay, 1973), in Sahiwal and Holstein Friesian (6.0 and 9.5) (Jian et al., 2014), and in Jersey cattle from different herds (6.16 to 7.82) (Barker and Nay, 1964). Sweat gland numbers $/ \mathrm{cm}^{2}$ in dewlap and thigh skin region of red sindhi cattle was found higher compared with other body regions. Reports on sweat gland density by Volcani and Schindler (1954) and McDowell (1958) suggested that sweat glands are distributed according to the decreasing evaporation from face, neck, dewlap legs and mid-belly line. Our results showed similarity with the above suggestion and demonstrate that sweat gland numbers was more in dewlap and thigh, while lower in abdomen, scrotum and udder skin region of in all age groups of both sexes of red Sindhi cattle.

\section{CONCLUSION}

This may be concluded from the current study that in skin of the red Sindhi cattle, epidermis and dermis range 41.1-50.13 $\mu \mathrm{m}$ and 443.97 to $597.05 \mu \mathrm{m}$, respectively. Skin layers develop with age and are different in thickness in both male and female groups. Skin appendages in young cattle are mainly distributed in papillary dermis layer, while in the adults they are distributed throughout the papillary and deeper areas in reticular dermis layer. Sweat glands have baggy to tubular shape and possess higher volume in dewlap and thigh region of adult age group, while numbers $/ \mathrm{cm}^{2}$ were more in the young age group.

\section{Statement of conflict of interest}

Authors have declared no conflict of interest.

\section{REFFERENCES}

Allen, T., 1962. Responses of Zebu, Jersey, and Zebu X Jersey crossbred heifers to rising temperature, with particular reference to sweating. Aust. J. agr. Res., 13: 165-179. https://doi.org/10.1071/AR9620165

Barker, J. and Nay, T., 1964. A study of sweat gland characters and their relationship to adaptation in jersey cattle. Proc. Aust. Soc. Anim. Prod., 5: 173180.

Beatty, D.T., Barnes, A., Taylor, E., Pethick, D., McCarthy, M. and Maloney, S.K., 2006. Physiological responses of Bos taurus and Bos indicus cattle to prolonged, continuous heat and humidity1. J. Anim. Sci., 84: 972-985. https://doi.org/10.2527/2006.844972x

Bianchini, E., McManus, C., Lucci, C.M., Fernandes, M.C.B., Prescott, E., Mariante, A.D.S. and Egito, A.A.D., 2006. Body traits associated with heat adaptation in naturalized Brazilian cattle breeds. Pesq. Agropec. Bras., 41: 1443-1448.

Britt, A.G., Cotton, C.L., Kellett, B.H., Pitman, I.H. and Trask, J.A., 1985. Structure of the epidermis of Australian Merino sheep over a 12-month period. Aust. J. biol. Sci., 38: 165-174. https://doi. org/10.1071/BI9850165

Dalman, H.D., 1993. Textbook of veterinary histology, 4 ed. Lea and Fibiger, Philadelphia. pp. 285-298.

Dowling, D., 1955. The hair follicle and apocrine gland populations of Zebu (Bos indicus L.) and short horn (B. taurus L.) cattle skin. Aust. J. agric. Res., 6: 645654. https://doi.org/10.1071/AR9550645

Ebling, F., Eady, R. and Leigh, I.,, 1992. Anatomy and organisation of human skin. In:. Textbook of dermatology (eds. R.H. Champion, J.L. Burrington, F.J.G. Ebling). $5^{\text {th }}$ ed. Blackwell Scientifc Publications, New York.

Findlay, J.D. and Robertshaw, D., 1965. The role of the sympatho-adrenal system in the control of sweating 
in the ox (Bos taurus). J. Physiol., 179: 285-297. https://doi.org/10.1113/jphysiol.1965.sp007663

Genkovski, D., and Gerchev, G., 2007. Study of the skin histological structure in ewes from Staroplaninska and Thoroughbred Tsigai. Biotech. Anim. Husband., 23: 191-197.https://doi.org/10.2298/BAH0702191G

Hafez, E.S.E., Badreldin, A.L. and Shafei, M.M., 1955. Skin structure of Egyptian buffaloes and cattle with particular reference to sweat glands. J. agric. Sci., 46: 19-30. https://doi.org/10.1017/S0021859600039587

Hahn, G.L., 1999. Dynamic responses of cattle to thermal heat loads. J. Anim. Sci., 77: 10-20. https://doi. org/10.2527/1997.77suppl_210x

Hossain, M.E., Uddin, M., Shil, S.K., kabir, M.H.B., Mahmud, M.S. and Islam, K.N., 2016. Histomorphometrical characterization of skin of native cattle (Bos indicus) in Bangladesh. Am. J. Med. biol. Res., 4: 53-65.

Humbert, P., Sainthillier, J.-M., Mac-Mary, S., Lihoreau, T., Fanian, F., Jeudy, A. and Li, L., 2017. Skin capillaroscopy. In: Agache's measuring the skin: Non-invasive investigations, physiology, normal constants (eds. P. Humbert, F. Fanian, H.I. Maibach and P. Agache), Springer International Publishing, Cham, pp. 549-562. https://doi.org/10.1007/978-3319-32383-1 60

Jenkinson, D.M. and Nay, T., 1968. Sweat gland and hair follicle measurements as indicators of skin type in cattle. Aust. J. biol. Sci., 21: 1001-1011. https://doi. org/10.1071/BI9681001

Jenkinson, D.M. and Nay, T., 1973. The sweat glands and hair follicles of Asian, African, and South American cattle. Aust. J. biol. Sci., 26: 259-275. https://doi. org/10.1071/BI9730259

Jian, W., Duangjinda, M., Vajrabukka, C. and Katawatin, S., 2014. Differences of skin morphology in Bos indicus, Bos taurus, and their crossbreds. Int. J. Biometeorol., 58: 1087-1094. https://doi. org/10.1007/s00484-013-0700-9

Kadzere, C.T., Murphy, M.R., Silanikove, N., and Maltz, E., 2002. Heat stress in lactating dairy cows: A review. Livestock Prod. Sci., 77: 59-91. https://doi. org/10.1016/S0301-6226(01)00330-X

Khan, M.S., Rehman, Z.U., Khan, M.A. and Ahmad, S., 2008. Genetic resources and diversity in Pakistani cattle. Pak. Vet. J., 28: 95-102.

Kobayashi, A., Takehana, K., Eerdunchaolu, Iwasa, K., Abe, M. and Yamaguchi, M., 1999. Morphometric analysis of collagen: A comparative study in cow and pig skins. Anat. Histol. Embryol., 28: 235-238. https://doi.org/10.1046/j.1439-0264.1999.00196.x

McDowell, R.E., 1958. Physiological approaches to animal climatology. J. Hered., 49: 52-61. https://doi. org/10.1093/oxfordjournals.jhered.a106766

McDowell, R.E., 1972. Improvement of livestock production in warm climates. W.H. Freeman and Company, San Francisco.

Markova, M.S., Zeskand, J., McEntee, B., Rothstein, J., Jimenez, S.A. and Siracusa, L.D., 2004. A role for the androgen receptor in collagen content of the skin. J. Invest. Dermatol., 123: 1052-1056. https:// doi.org/10.1111/j.0022-202X.2004.23494.x

Mobini, B., 2012. Histology of the skin in an Iranian native breed of sheep at different ages. J. Vet. Advan., 2: 226-231.

Muralidharan, M.R., and Ramesh, V., 2005. Histological and biochemical studies of the skin of cattle and buffalo. Indian J. Anim. Res., 39: 41-44.

Nascimento, M.R.B.d.M., Dias, E.A., Santos, T.R.d., Ayres, G.F., Nascimento, C.C.N. and Beletti, M.E., 2015. Effects of age on histological parameters of the sweat glands of Nellore cattle. Rev. Ceres Viçosa. 62: 129-132. https://doi.org/10.1590/0034737X201562020001

Nay, T., and Hayman, R., 1956. Sweat glands in Zebu (Bos indicus L.) and European (B. taurus L.) cattle. I. Size of individual glands, the denseness of their population, and their depth below the skin surface. Aust. J. agric. Res., 7: 482-492. https://doi. org/10.1071/AR9560482

Pan, Y., 1963. Quantitative and morphological variation of sweat glands, skin thickness, and skin shrinkage over various body regions of Sahiwal Zebu and Jersey cattle. Aust. J. agric. Res., 14: 424-437. https://doi.org/10.1071/AR9630424

Petrishchev, B.I. and Lebengarts Ia, Z., 1993. The morphology and postnatal development of the skin in purebred and mixed-breed cattle (Bos taurus). Ontogenez, 24: 51-61.

Sajid, M.S., Iqbal, Z., Khan, M.N., Muhamamd, G. and Iqbal, M.U., 2007. Effect of Hyalomma ticks (Acari: Ixodidae) on milk production of dairy buffaloes (Bos bubalus bubalis) of Punjab (Pakistan). Italian J. Anim. Sci., 6: 939-941. https://doi.org/10.4081/ ijas.2007.s2.939

Schleger, A. and Turner, H., 1965. Sweating rates of cattle in the field and their reaction to diurnal and seasonal changes. Aust. J. agric. Res., 16: 92-106. https://doi.org/10.1071/AR9650092

Shalimov, N.A., and Katsy, G.D., 1989. Dynamics of the histological structure and function of the skin during adaptation of Angler cattle of various constitutional types. Tsitol. Genet., 23: 10-14.

Sultan, G., 2012. Comparative histological and 
topographical study for the skin of head of male and female native black goat. Iraqi J. Vet. Sci., 1: 21-33.

Tarique, I., Vistro, W.A., Bai, X., Yang, P., Hong, C., Huang, Y., Haseeb, A., Liu, E., Gandahi, N. S., Xu, M., Liu, Y. and Chen, Q., 2019. LIPOPHAGY: A novel form of steroidogenic activity within the LEYDIG cell during the reproductive cycle of turtle. Reprod. Biol. Endocrinol., 17:19. https:// doi:10.1186/s12958-019-0462-2

Turner, H., and Schleger, A., 1960. The significance of coat type in cattle. Aust. J. agri. Res., 11: 645-663. https://doi.org/10.1071/AR9600645

Udo, H.M.J., 1978. Hair coat characteristics in Friesian heifers in the Netherlands and Kenya: Experimental data and a review of literature. Veenman, Wageningen, pp. 78-86.

Vella, F., 1994. Molecular biology of the cell.Garland Publishing, Biochemical Education, New York and London. 22: 164-164. https://doi.org/10.1016/03074412(94)90059-0
Volcani, R. and Schindler, H., 1954. Physiological reactions of dairy cows in various seasons and in different regions of Israel. Refuah Vet., 11: 174-177.

Wahid, A., 1975. Livestock resources of Pakistan monograph. Red Sindhi cattle. Reproduction, 14: 112-113.

Widelitz, R.B., Jiang, T.X., Noveen,A., Berreth, S.A., Yin, E., Jung, H.S. and Chuong, C.M., 1997. Molecular histology in skin appendage morphogenesis. Micro. Res. Tech., 38: 452-465. https://doi.org/10.1002/ (SICI)1097-0029(19970815)38:4<452::AIDJEMT13>3.0.CO;2-I

Yang, X., Cui, Y., Yue, J., He, H.H., Yu, C., Liu, P.G., Liu, J., Ren, X.D. and Meng, Y., 2017. The histological characteristics, age-related thickness change of skin, and expression of the HSPs in the skin during hair cycle in yak (Bos grunniens). PLoS One, 12: e0176451. https://doi.org/10.1371/journal. pone. 0176451 